Int. J. Dev. Biol. 53: 1245-1252 (2009)

doi: $10.1387 / \mathrm{ijdb} .082612 \mathrm{~mm}$

\title{
The teaching of Developmental Biology in Spain: future challenges ${ }^{\#}$
}

\author{
MANUEL MARÍ-BEFFA* \\ Department of Cell Biology, Genetics and Physiology, Faculty of Science, University of Málaga \\ and CIBER-BBN, Málaga, Spain
}

\begin{abstract}
Developmental biology and/or embryology prospectuses in Spanish universities are reviewed. From old masterly classes to virtual teaching, a variety of methods are being used nowadays to teach these subjects. In a country like Spain, adapting to the European Higher Education Space, old and new teaching methods are educational alternatives in a university model which respects both tradition and modernity. In this report, consensus guidelines, concluded from this general survey, are suggested for teachers to ensure future progress.
\end{abstract}

KEYWORDS: teaching, embryology course, biology curriculum, medicine curriculum, veterinary curriculum

\section{Introduction}

In this paper, I aim to offer guidelines obtained from a survey of our current teaching programs on developmental biology and embryology at Spanish universities. I will discuss how these subjects are influenced by both scientific research and the academic interests of each university with a wider cultural background (Ortega y Gasset, 1930). Finally, old and modern teaching methods are discussed as stimulating options in prospectuses nowadays.

\section{From basic to applied science}

\section{The teaching prospectus at Secondary Schools}

The Spanish Ministry of Education and Science, precursor of the current Ministry of Education, published in 2007 the basic structure of the last two years of Secondary School (www.boe.es/ boe...). The Ministry provided minimal teaching standards of several courses. A common course, Science for Contemporary World, and two specific ones, Biology and Biology and Geology, are somehow related to Developmental Biology. In the minimal teaching of Sciences for Contemporary World, four topics related to "To live more and to live better" are considered. The fourth one is "Assisted Reproduction, Cloning and Applications, Stem Cells and Bioethics" (about 5 hours) which could be related to our discipline of interest. In assessment criteria, the Spanish decree explains that "... the student must know the scientific basis of genetic and embryological manipulation. This must lead the student to understand the pros and cons of the application of these techniques and the international arguments about Bioethics". Concepts of embryology or developmental biology, neither in Biology nor in Biology and Geology courses, are explicitly suggested. However, and due to previous programs, classes of embryology are expected to be taught related to histology which now appears in a Biology and Geologycourse in the new decree.

Indeed, previous teaching programs at Secondary Schools in Spain (www.uclm.es...) spent about 14 hours (12-13\%) of the course Biology and Geology to embryology teaching. Themes such as embryonic cleavage, gastrulation, coelom formation, organogenesis, growth, sexual and asexual reproduction, and life cycles were taught. These themes represented about $1.4 \%$ of the complete education that year. This was probably a good way for initiating the learning of developmental biology. These classes were taught among a wide variety of different biological and geological topics and followed lessons on reproduction and cell mitosis. Young students were able to learn basic embryology, and its relationship with evolutionary theory, before taking their university entrance examination. Expectations exist about how the new minimal teaching will be interpreted (e.g. www.juntadeandalucia...).

\footnotetext{
Abbreviations used in this paper: CABD, Centro Andaluz de Biología del Desarrollo; CR, compulsory ratio; ECTS, European Credit Transfer System; EHES, European Higher Education Space.
}

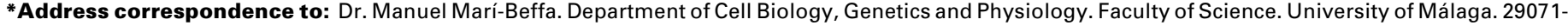
Málaga. Tel: +34-952-13-2398. Fax: +34-952-13-1937. e-mail: beffa@uma.es - Web: http://webpersonal.uma.es/ BEFFA
}

\#Note: In memory of Alicia María Marí-Román, a student at Granada University with a truncated promising career.

Final author-corrected PDF published online: 11 November 2009. 
TABLE 1

DISTRIBUTION OF NUMBER OF DEVELOPMENTAL BIOLOGYRELATED SUBJECTS WITHIN THE TEACHING PROGRAM OF THE UNDERGRADUATE BIOLOGY IN 27 SPANISH UNIVERSITIES

\begin{tabular}{ccccc} 
Subject types & Embryology & Dev. Biol. & Plant Dev. & Reprod. Biol. \\
\hline Basic 2 * & - & 1 & - & - \\
Compulsory 1 & 3 & - & 1 & - \\
Compulsory 2 & 2 & 3 & 1 & - \\
Optional 1 & 4 & 3 & 2 & 1 \\
Optional 2 & 5 & 18 & 7 & 6 \\
\hline
\end{tabular}

* 1 or 2: First (three years) or second (two years) teaching cycle, respectively.

In principle, with regards to developmental biology, changes are occurring to re-direct teaching programs at Spanish Secondary Schools. These programs are being modified from a basic science (e.g. from reproduction to evolution) to an applied science view (e.g. from bioethics to biomedicine).

\section{The teaching prospectus at universities}

\section{The "applied" question}

Until very recently, universities were organized according to professorships. These professorships were based on doctorate studies in their foundational stages. This was the real bases for an organization of topics in the bachelor degree. However, in recent years the promotion of academic growth has depended on the socalled knowledge areas. This facilitated economic investments and the organization of teaching, departments and faculties in our 76 universities where the transference of scientific information to students was taking place.

Each Spanish knowledge area (under revision nowadays) was a reflection of its own history. "Cell Biology", "Zoology" or "Genetics" were distinct areas with their own historical identity. A clear example of this was observed in the "Human anatomy and embryology" knowledge area. Human anatomy, including its embryology, has been a subject taught in old medicine faculties for more than five hundred years. Moreover, outstanding results have been obtained from Spanish medical scientists in this, or related, matters. Michael Servetus and Santiago Ramón y Cajal are the best examples. Besides these, no clear institutional recognition could be seen with regards to animal or plant embryology or developmental biology, even if ancient veterinary or overseas botany in Spain is considered.

The complete teaching prospectus at universities nowadays although disappearing during the next few years - is divided into cycles. The first cycle includes basic courses (three years). The second cycle teaches advanced-level courses (two years). The third cycle (post-graduate cycle) includes doctorate preparation. Courses are divided into Basic, Compulsory for each university and Optional. Diploma or technical engineering curricula require a first cycle. Bachelor or engineering curricula include both a first and a second cycle. Topics in each degree are under the responsibility of one, or several, knowledge area(s) irrespective of the organization of the department or teacher affiliation. New modifications proposed by the Spanish Government consider only two cycles: a graduate -the grade - and a postgraduate - the postgrade - cycle (www.boe.es/dias...). These are similar to undergraduate and graduate in other countries and will begin with this 2009-10 academic year. My main argument is based in old programs and it
TABLE 2

\section{DISTRIBUTION OF NUMBER OF DEVELOPMENTAL BIOLOGY- RELATED SUBJECTS WITHIN THE TEACHING PROGRAMS OF MEDICINE AND VETERINARY BACHELORSHIP IN 31 SPANISH UNIVERSITIES}

\begin{tabular}{cccccccc} 
& \multicolumn{3}{c}{ Medicine (29) * } & & \multicolumn{3}{c}{ Veterinary (11) } \\
\cline { 2 - 4 } Subject types & Embryol. & Dev. Biol. Reprod. Biol. & & Embryol. & Dev. Biol. Reprod. Biol. \\
\hline Basic 1 ** & 24 & 2 & 3 & & 12 & - & 1 \\
Basic 2 & - & - & 38 & & - & - & 15 \\
Compulsory 1 & - & 2 & 1 & & - & - & 2 \\
Compulsory 2 & - & 1 & 2 & & - & - & - \\
Optional 1 & 4 & 5 & 2 & & - & 1 & 1 \\
Optional 2 & 2 & 4 & 6 & & - & - & 1 \\
\hline
\end{tabular}

* Numbers in parenthesis indicate number of surveyed universities.

** 1 or 2: First (three years) or second (two years) teaching cycles, respectively.

could only be applied to a future graduate cycle - the teaching of a complete internationally-established discipline -.

According to old programs, the Spanish Ministry of Education and Science also provided institutional guidelines for basic courses in the teaching prospectus. In veterinary or human health related degrees (medicine, nursery, physiotherapy, dentistry or podiatry) the Ministry provided some guidelines about developmental biology. In these degrees it was suggested that embryology, growth or development should be taught as main basic topics. Unfortunately, in degrees such as biology, biochemistry, biotechnology, and also marine science, agronomic engineering or agricultural technical engineering degrees, developmental biology was completely absent. In these degrees, only suggestions of an embryological description, development or culturing of plants and animals were considered. Zoology (to explain the classical embryological basis of taxonomy) and plant physiology (the old Entwickelungsphysiologische) courses and areas have been responsible in Biological degrees. A number of other different areas have been suggested to teach plant and animal culturing in engineering degrees.

Regardless of these guidelines, in each Spanish Bachelorship of Biology efforts have been made to teach developmental biology. As a matter of fact, only one university lacks developmental biology-related courses in its biology teaching prospectus. The following table shows the distribution throughout the cycles of

TABLE 3

\section{DISTRIBUTION OF NUMBER OF DEVELOPMENTAL BIOLOGY- RELATED SUBJECTS WITHIN THE TEACHING PROGRAM OF UNDERGRADUATE BIOLOGY IN 11 FOREIGN UNIVERSITIES}

\begin{tabular}{ccccc} 
Subject types & Embryology & Dev. Biol. & Plant Dev. & Reprod. Biol. \\
\hline Compulsory 1 & - & - & - & - \\
Compulsory 2 & 1 & 4 & - & - \\
Compulsory 3-4 & 1 & 5 & - & 1 \\
Optional 1 & - & - & - & - \\
Optional 2 & 1 & 2 & - & - \\
Optional 3-4 & 1 & 16 & 3 & 1 \\
\hline
\end{tabular}

* 1-4: first to fourth undergraduate academic year.

Note: This data have been obtained from Int. J. Dev. Biol. Special Issue on Teaching Developmental Biology (Vol. 47, Nos. 2/3 (2003)) and official web-pages of the universities of Bath Bordeaux, Brown, Calgary, Indiana (Bloomington), Manitoba, Palermo, Pisa, Queensland, Rider and Uppsala. 
subjects dedicated to the teaching of embryology and/or developmental biology and related topics such as reproductive biology (Table 1). Most of these courses devote between 45 to 60 hours $(1.5-2 \%)$ to this topic. These hours are mainly distributed in the second cycle as optional among 15 to 50 other unrelated courses. When this distribution is studied in other programs, such as medicine or veterinary science (Table 2), the view is quite different. Most courses dedicated to embryology are distributed in the first cycle and they are considered basic or compulsory. Those dedicated to reproductive and developmental biology are distributed in the second cycle. Irrespective of other considerations, these results are illustrative of scientific academic politics in Spain with regards to this matter. Under a general scope, again applied science might be preferentially considered versus basic science. The other bachelor, diploma, engineering or technical engineering curricula show a similar profile. Applied scientific disciplines display some teaching dedication to this topic in the first basic cycle. But in basic scientific-related degrees (such as Biochemistry or Biotechnology), developmental biology is restricted to optional second cycle courses or absent (see http://www.educacion/ universidades..).

Finally, Table 3 shows the distribution of developmental biology-related subjects in eleven foreign universities. In order to compare these Tables, I propose a simple compulsory ratio (CR $=$ number of compulsory subjects divided by the total number of subjects). Spanish biology shows a CR of 0.19 (Table 1), whereas Spanish medicine and veterinary show ratios of 0.76 and 0.91 (Table 2), respectively. However, foreign biology teaching sample shows a CR of 0.33 (Table 3), higher than Spanish biology CR but still lower than Spanish medicine or veterinary CRs. According to this index, developmental biologyrelated subjects may be considered less important by Spanish biologists than in other countries. Recent news suggests that new biology grade will include developmental biology as a specific competence (Sánchez Carralero, 2004). However, no sign suggests that the compulsory ratio (Table 1 ) will be increased. This is clearly associated to the historically-based driving of the science teaching in Spain from a basic to an applied view.

\section{Number of students}

A second interesting aspect of this study can be found when the number of students signing up for these disciplines is considered. The abovementioned degrees are a preferential choice for any student who decide to study away from home due to lack of proper academic offer in her/his own city. In fact, Health Sciences occupied five of the top six disciplines in the preference list. Biology was located in the $11^{\text {th }}$ position of all teaching programs (more than 50 degrees). Moreover, the enrolment in the first year A

\section{Valencia}

Barcelona

Co San.

\section{Ovied}

\section{nuarars}

Murcia

Aut. Barc.

autu

León

Coruña

Pom. Fab.

Girona

Jaén of all degrees offering embryology and/or developmental biology in Spain is 25,725 students (2006-2007 enrolment) - only 4,343 in Biology -. This means that during 2006-2007 academic year, about 26,000 students started a degree in which they will be able to choose some courses related to developmental biology. Irrespective of the above-mentioned problems, Spanish universities are providing enough education to a clearly important population of Spanish students (data obtained from former www.mec.es (2007)).

\section{Coordination between science and science teaching}

A third aspect is related to each theme which is taught in developmental biology courses. According to available course prospectuses, Table 4 plots all major embryological and developmental biology themes, from early embryogenesis to applied computation, against 21 out of 27 universities with bachelor of

TABLE 4

\section{DISTRIBUTION OF EACH EMBRYOLOGICAL AND DEVELOPMENTAL BIOLOGY SUBJECT IN THE UNDERGRADUATE BIOLOGY PROSPECTUS OF 21 SPANISH UNIVERSITIES (TEACHING “MICROARRAY”)}

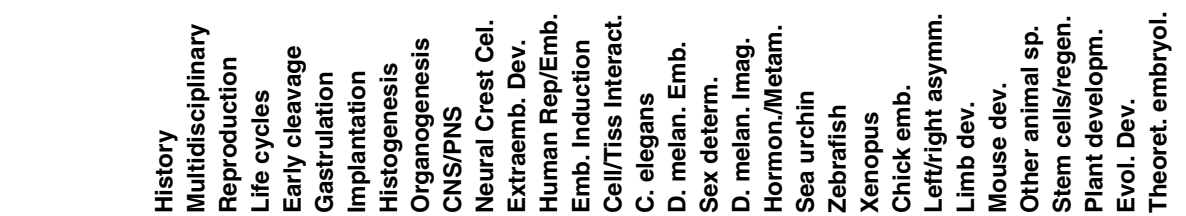

Salamanca

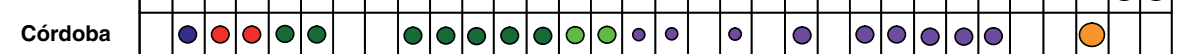

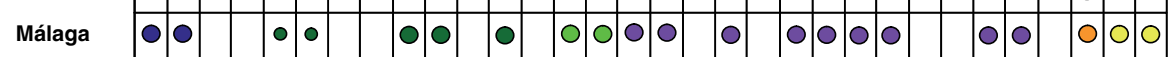

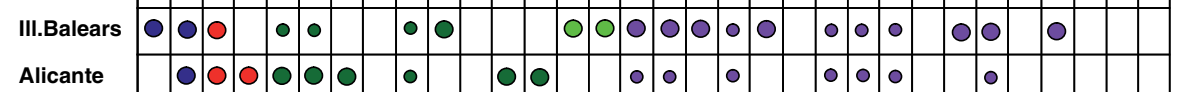

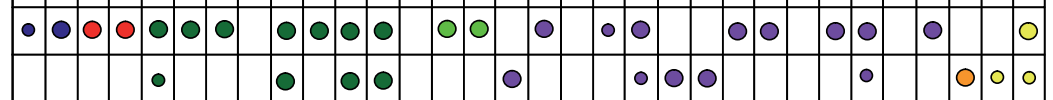

\begin{tabular}{|c|c|c|c|c|c|c|c|c|c|c|c|c|c|c|}
\hline 100 & 10.0. & \begin{tabular}{|l|l|}
0 & 0 \\
\end{tabular} & & 10 & 0.0 & 0 & 0.0 & 0 & $\begin{array}{llll} & 0 & 0\end{array}$ & 0. & 00 & c & & 0 \\
\hline 0 & | 0.00 & $\begin{array}{lll} & 0 \\
\end{array}$ & & 0 & & & 0 & 0 & & & & & & \\
\hline - & 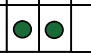 & \begin{tabular}{|l|l|l|}
0 & 0 \\
\end{tabular} & 00 & & \begin{tabular}{l|l|l}
0 & 0 & 0 \\
\end{tabular} & 0 & & 0 & \begin{tabular}{|l|l|l} 
& 0 & 0 \\
\end{tabular} & & & o & & \\
\hline
\end{tabular}

Each row represents a different university, while each column represents a different theme. Selected Spanish universities that offer a bachelor of biology were chronologically ordered according to their stated founding dates. Developmental biologyrelated subjects ordered and colour-coded as follows: blue: general; dark green: embryology; light green: experimental embryology; violet: developmental biology; red: reproductive biology; orange: plant developmental biology; and yellow: interdisciplinary themes. Circle sizes: percentage of the approximate time spent on each teaching theme in relation to a standard developmental biology/embryology average prospectus (small: slightly explained; medium: explained in an average time; large: over-explained). 
biology studies (77\% sample) ("Teaching microarray"- from http:/ /www.educacion.es/educacion/universidades...). Universities are arrayed according to their stated chronological foundation. Each developmental biology theme is ordered and colour-coded, ranging from more general embryological descriptions to modern molecular biology and Evo-Devo. The observed results remind one of the half empty/half filled glass of wine (36\% empty; $64 \%$ filled). From a positive view, almost all universities provide some preparation on embryology and developmental biology to students. From a negative view, this preparation covers almost all important subjects in just few instances. All this may reflect the heterogeneous transient situation in our developmental biology teaching prospectuses, away from strict guidelines characteristic of well-established disciplines. Indeed, Spanish universities hardly teach themes such as histogenesis, human embryology, sex determination, limb axes molecular biology or theoretical embryology in these courses. As a surprise, even wing imaginal disc development (see Ghysen, 2009), or stem cells and regeneration biology, are only taught in about half of the developmental biology-related courses at sampled universities. This situation might be a clear consequence of a lack of coordination between international scientific research projects and teaching.

Bachelorship of Biology is important for developmental biology teaching in foreign universities (e.g. Grunz, 2003). If we compare our universities with foreign universities around the world the view is quite satisfactory. Developmental biology-related teaching in foreign universities shows about $62 \%$ of optimal conceptual explanations in their "teaching microarray" (Table 5). This is indeed similar to our $64 \%$ filling. These results provide a different scope to the problem. Probably, the Spanish discrepancies previously discussed are widely dependent on international projects on science teaching from which Spanish teachers may be amply devoted. In this context, also creationism vs. evolutionary international debate is also implicit in the teaching programs of a number

TABLE 5

\section{DISTRIBUTION OF EACH EMBRYOLOGICAL AND DEVELOPMENTAL BIOLOGY SUBJECT IN THE UNDERGRADUATE BIOLOGY PROSPECTUS OF 7 FOREIGN UNIVERSITIES (FOREING "MICROARRAY")}

\begin{tabular}{|c|c|c|c|c|c|c|c|c|c|c|c|c|c|c|c|c|c|c|c|c|c|c|c|c|c|c|c|}
\hline & 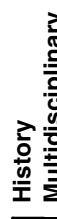 & & & & & & & & & & & & & & & & & & & & & & & & & & \\
\hline sa & 0 & & & 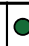 & 0 & & & 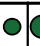 & $T$ & 0 & & c & 0 & $\mathrm{C}$ & & & & 0 & & $\mathrm{DC}$ & & o & 0 & & & O & \\
\hline Jppsala & & $c$ & כ & 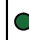 & 0 & O & O & 0 & 0 & 0 & 0 & & 0 & C & $c$ & & & 0 & & oc & & c & 0 & & 0 & o & \\
\hline Essen & 0 & $\mathrm{DC}$ & & 0 & 0 & & 0 & 0 & 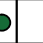 & & 0 & 0 & & $c$ & & 0 & 0 & 0 & & 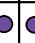 & & & 0 & & 0 & O & \\
\hline Bath & \begin{tabular}{l|l}
0 & \\
\end{tabular} & 0 & $\mathrm{DC}$ & 0 & 0 & 0 & 0 & 0 & 20 & 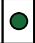 & 0 & 이 & 0 & 3 & & 0 & & & & $\partial c$ & 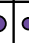 & & J & & 0 & 0 & \\
\hline Tokyo & 0 & $\mathrm{DC}$ & 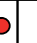 & 0 & 0 & & & 0 & 0 & & & O & 0 & & & & 0 & & & b & & & & & 0 & & 0 \\
\hline Queensland & 8 & 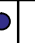 & 0 & |c & 0 & & 1 & or & 5 & & 인 & & 0 & 0 & & 0 & & & 이 & oc & & & & 0 & 0 & O & \\
\hline ont. Ecuad. & 0 & 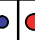 & 0 & C & 0 & & 0 & - & 0 & 10 & & & $c$ & $c$ & & 0 & & & 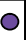 & 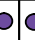 & & & & 0 & & 010 & \\
\hline
\end{tabular}

Each row represents a different foreign university, while each column represents a different theme as in Table 4. Selected Foreign universities that offer a bachelor of biology were chronologically ordered according to their founding dates. Developmental biology-related subjects are ordered and colour-coded as in Table 4. Circle sizes: percentage of the approximate time spent on each teaching theme in relation to a standard developmental biology/embryology average prospectus (small: slightly explained; medium: explained in an average time; large: over-explained). universities have been selected from Int. J. Dev. Biol. 43 (2003). of Spanish universities. This is important in the search of a future gle world-wide explanation of our lives in nature, but is quite couraged the uncoordinated behaviour.

In general, I conclude that Spanish developmental biology teaching is updated to its international counterpart (compare Table 4 and 5). This is hopefully due to the personal effort of each ally similar to international teachers, even, as suggested some-

\section{Teaching from abroad: material for spanish teachers}

\section{Theory}

How does the future hold? The university teacher's job is protected by law. Academic freedom and employment stability or specific details of their classes, whether theoretical or practical. However, courses are always dependent on each department Due to Tables 4/5 comparison, we might persuade teachers to maintain updating of their prospectus according to an international optimum. This is a feasible project, something handy for each teacher although not easy to achieve, as all themes are not included in most textbooks on this topic (see Browder, 2003). Indeed, there are only two books on developmental biology, Gilbert (2005) and Wolpert et al. (2010), which have been translated into Spanish, and only a few translated books on embryology (e.g. Houillón, 1977; Carlson, 2000).

Although Spanish authors have published many international textbooks including concepts of embryology during the long history of Spanish universities, nowadays the view is quite different. When we consider all textbooks used by Spanish teachers of developmental biology in the Spanish biology bachelorship, two conclusions are obtained: (1) there are very few textbooks written by Spanish teachers; and (2) there are no consensus guidelines on this topic with regards to the usage of teaching books. According to each course prospectus, 180 different books related to this topic are used by all teachers of the 34 developmental biology-related courses in the 19 universities reviewed for this report. However, only 13 books are used by more than 6 teachers. 
The book used by most teachers is Developmental Biology by Scott Gilbert in any edition, either English or Spanish. However, the second book in the list is Molecular Biology of the Cell (any edition), by Bruce Alberts et al. (see Alberts et al., 2002), an interesting textbook for cell biology but insufficient for developmental biology or embryology. For developmental biology, and in third position, the book by Lewis Wolpert and colleagues, Principles of Development, clearly fits the expected needs by teachers on this discipline (Wolpert et al., 2010) (data from www.educacion.es/educacion/universidades...).

Probably, five to six books are available in scientific bookstores which might complement the above-mentioned books by Gilbert (2005) and Wolpert et al. (2010). For a general view of this offer, some of these books are shown in Table 6 with the actual frequency of teaching usage. In general, teaching usage may be a feasible consensus guideline of teaching material for developmental biology theory from abroad.

\section{Laboratory courses}

A general conclusion emerges when practice labs are compared in 21 universities teaching biology classes: each teacher gives practice labs close to their personal experience. When anyone attends international congresses on the teaching of science (e.g. ensciencias.uab.es) local efforts of each teacher in their practice labs of any scientific discipline can be seen. However, no guidelines can be deduced from these observations. Can consensus guidelines be developed?

There have been some efforts towards developing guidelines during the recent history of Spanish universities. A laboratory guidebook was published in Barcelona, by Catalan teachers in Spanish language, to introduce students to the subject (Prácticas de Biología (1978) Editorial Fontalba, Barcelona). Books by García del Moral et al. (1979); Sánchez Díaz et al. (1980), and Simon and Moysset (2001) should also be considered a starting point. However, all national or international laboratory books are used by only one or two Spanish teachers. This observation once again suggests a wide variety of offerings at Spanish universities.

During 11 years (1996-2008), I have been doing laboratory exercises on Drosophila imaginal developmental genetics at the University of Málaga (founded in 1972). This teaching experience led me to edit a laboratory guidebook (Marí-Beffa and Knight, 2005; www.cambridge.org/catalogue/..). This book (see below) may also help teachers to find a general guideline in an inquirybased lab format (see Malacinski, 2003; Harwood, 2003).

\section{Teaching methods: techniques serving teaching aims}

\section{Old teaching methods: "to copy or not to copy, that is the question"}

The classical Spanish teaching method since XIII century is masterly classes (García Simón, 1995). All universities use this type of teaching. Discussions about modifications of those methods often turn ugly. Moreover, many teaching activities complementing this technique (from chalk and blackboard to Microsoft Power Point presentations) have been used since then.

Probably, the most important challenge Spain has accepted in science teaching was developed in the scientific humanistic program, the first attempt for international updating. This teaching program used two complementary methods: the philological and the "autopsy" methods (López-Ocón Cabrera, 2003). The philological method was "to copy" by translation interesting books written in Latin, or any other language, into either Spanish or Latin. The "autopsy" method - "not to copy" - was designed as a revolution against authority (ex cathedra) principles (Bustamante, Claustral book of Salamanca University, 1550). Using this method, the student might verify the knowledge of any scientific text by self-experience "(sight) with her/his own eyes". "Autopsy" method was not restricted to descriptions of human anatomy, but it could be applied to any biological or scientific discipline, normally agriculture in those years. As suggested by Juan Luis Vives (1492-1540) in his De disciplinis (1531), the detailed observation of res naturae - the experimentum - represents a rejection to scholastic dialectics. In current scientific context this could be an actual empirical observation. Spanish students such as Andrés Laguna (1535) (Anatomica Methodus) and Michael Servetus wrote works that disputed classical authors. The pulmonary blood circulation discovery, and the use of embryological data to support his discovery against Galen's descriptions, was the best Spanish example of the "autopsy" method (López Piñero et al., 1983a and b; López-Ocón Cabrera, 2003).

\section{Current teaching methods}

Science teaching has evolved through these centuries leading to actual formal teaching programs. Indeed, the world is undergoing an "information transfer" revolution. Internet, TV or radio scientific programs, cooperative or virtual teaching methods are just some of the most widely-spread communication strategies operative in modern societies. Most universities in America, Europe, Australia or Japan, and some in Asia or Africa (e.g. www.natureasia.com; www.exclusivebooks.com), use these types of methods and this of course influences developmental biology teaching at universities.

\section{"To copy ..."}

Initially, a possible basic activity might be the translation of some of the above-mentioned English-written books into Spanish. This is urgent for the complete development of these disciplines in our universities. Several universities have initiated bilingual (Spanish, Catalan, Galician, Basque or English) (e.g. the Spanish-English program at the University of Málaga) prospectus in several Degrees (data from www.educacion.es/educacion/ universidades...). Moreover, textbooks are lacking in any of the languages (except English) used to teach either developmental biology or any embryology-related subjects. Unless an English prospectus is incorporated, translation of the above-mentioned books, possibly those at the top of the usage list, into Spanish,

TABLE 6

\section{TEACHING USAGE OF EMBRYOLOGICAL AND DEVELOPMENTAL BIOLOGY TEXTBOOKS IN 34 SUBJECTS AT 19 SPANISH UNIVERSITIES}

\begin{tabular}{cccc} 
Textbooks & Embryology & Textbooks & Dev. Biol. \\
\hline Carlson, any edition & 14 & Gilbert, any edition & 28 \\
Langman (Sadler), any edition & 10 & Alberts et al., any edition & 15 \\
Moore \& Persaud, any edition & 7 & Wolpert et al., any edition & 14 \\
Kalthoff, 2001 & 6 & Slack, any edition & 6 \\
Bard, any edition & 6 & Martínez-Arias \& Stewart, 2002 & 5 \\
\hline
\end{tabular}


Catalan, Galician or Basque is one of the real needs this discipline has in its natural progress of modernization of Spanish universities. This would be a reflection of the old philological method in present day European Spain.

Besides this classical approach, modern teaching strategies, influenced by the internet, are being used to update developmental biology and embryology education in Spain. Some universities provide virtual teaching and E-learning (e.g. Oviedo (1608) and Córdoba (1972)), while other universities provide international web resources (www.educacion.es/educacion/universidades...) to students. I also encourage the use of these modern technologies in Spanish universities under the same translation principle that inspired our teaching past. These modern strategies are also at an experimental stage in most of the world's prominent international universities (e.g. www.uwex.edu/ce/; www.cooperation.org; www.newhorizons.org; Key and Nurcombe, 2003).

\section{"...not to copy..."}

Finally, in Marí-Beffa and Knight (2005), we have tried to revive the second old teaching method: the "autopsy" method. International and national developmental biologists describe in detail low-cost foundational experiments (e.g. by Driesch, Hörstadius, Lewis, Meyerowitz, Horvitz, Nüsslein-Volhard, García-Bellido, Gurdon, or Meinhardt among 27 chapters). The aim of this book is just a first attempt to provide students with the possibility of observing with their own eyes, at a lab bench, the actual results of these key experiments (see Worrell, 2007; Tyler et al., 2003). This critical thinking approach (see also Adams, 2003), may stimulate science progress as in the former period of scientific humanism. The possibility of arguing against the internationally reputed scientists (Ramón y Cajal, 1981) is a very stimulating thought.

The above mentioned teaching methods are, in the end, nonexclusive alternatives which will probably be adapting to each other during these coming years.

\section{From third cycle to scientific schools and job}

Postgraduate prospectuses in Spain include doctorate programs, masters (Official Prospectus), specialization courses, lifelong learning (according to Grundtvig or Leonardo da Vinci programs [see below], www.ec.europa.eu/education/lifelong...), and different individual programs at each university. These alternatives are chosen after graduation and initiate the student's professional life. However, very few postgraduate programs include developmental biology training in research (e.g. Miguel Hernández and Autónoma de Madrid universities). Indeed, only one university can be found to teach a program (master level) exclusively dedicated to developmental biology or embryology (Barcelona University. www.educacion/universidades...). The availability of a minimum number of students and specialized teachers are somehow restrictive.

\section{Basic developmental biology}

Once her/his studies are finished, the student may also choose a developmental biology lab to conduct her/his research (the natural development of the "not to copy" teaching principle). Although during the last century some important, internationally reputed scientific schools on developmental biology have emerged in Spain, two schools are of special importance: Cajal's School of Neurohistology which used an inductive approach (Puelles, 2009), and García-Bellido's School of Developmental Genetics which uses a deductive approach (Ghysen, 2009).

The relationship between teacher and students displayed by the first school was described by Santiago Ramón y Cajal. After Dr. Achúcarro's death, Ramón y Cajal wrote in 1918 a brief panegyric on his deceased student (Durán Muñoz and Alonso Burón, 1983):

"Nuestro querido y admirado compañero el doctor Achúcarro, uno de los miembros más activos y entusiastas de nuestra corporación... Como todo docente de vocación, Achúcarro convivía familiarmente con sus educandos, vigilaba de cerca sus ensayos, les alentaba en sus decepciones técnicas, les sugería ideas directrices $y$, en fin, les orientaba incansablemente en la bibliografía, que conocía a fondo y de primera mano."

Ramón y Cajal, who based his nervous system cellular theory on embryological data, admired the dedication to science of Achúcarro. In this text, Ramón y Cajal describes the dedication that a teacher must show at the lab-providing ideas, suggesting references and correcting deceptions -. These are features that any teacher of developmental biology must show in her/his classrooms and laboratories. A similar experience was lived in Antonio García-Bellido's School of Developmental Genetics (Ghysen, 2009). This innovative effort has led Profs. Ginés Morata and Peter Lawrence to successfully receive the "Principe de Asturias" award in 2007 (www.fundacionprincipedeasturias. org/esp/index.html), and to several other students to found the Andalusian Centre of Developmental Biology (CABD, Seville, www.upo.es/CABD). These are important outcomes which will hopefully stimulate internationalization of Spanish developmental biology.

\section{Applied developmental biology}

As discussed above, teaching driven by basic science is now changing to be driven by applied science, the old academic view. Nowadays, many different professional offers for embryologists exist in health sciences, veterinary, agriculture or marine science. New collaborations are arising between developmental biology labs (among other biological disciplines) and biomedical companies (e.g. Muñoz-Chápuli et al., 2004; Marí-Beffa et al., 2007). The future will probably favour this type of approach as a reflection of the suggestions by Spanish government (http://web.micinn.es/).

\section{The EHES and ALC/UE: new teaching tools for adapta- tion to Europe and maintenance of our historical iden- tity}

Europe adaptation programs have recently emerged to consolidate Spanish representation at the European Union. Under this scope, a European Higher Education Space (EHES) with several specific programs has been approved for development (Bolonia, 1999; www.ec.europa.eu/education/policies ..). One of the most interesting programs, "European Community Action Scheme for the Mobility of University Students" (ERASMUS), permits students to travel through member states. It integrates the ECTS, "European Credit Transfer System", by which the European Union promotes free movement to students throughout member states and thereby facilitating international academic 
recognition. Thus, ECTS is a non-centralized system of mutual reliance and is also being adopted by developmental biology prospectus in Spanish universities. In practical terms, during these years the number of international students will surely increase. This new EHES Bologna style has prompted a small revolution in Spanish universities, and many different programs (e.g. graduate and post-graduate prospectus, learning evaluation improvement or ECTS-dependent degree homologation and rehomologation programs (www.ec.europa.eu/education/ ..) have been proposed to adapt to this EHES.

Another program, ALC/UE, promotes the formation of the Common Space for Higher Education between European Union and Latin America and EI Caribe (www.oui-iohe.org/eles..). These activities will also permit consolidating collaborations among universities and establishing new coordinated networks for developmental biology teaching (see Del Pino, 2003).

During the long history of Spanish universities we have experienced many events that isolated us from Europe (López-Ocón Cabrera, 2003). Such events include Habsburg decay (XVI century), Novator movement and European nuova scienza (XVII XVIII centuries), and post-Napolean period (XIX century). This isolation has directed a special type of academic growth which has inhibited a quick updating of scientific affairs. In our European Spain, the EHES represents another opportunity to engage scientific frontiers and promote internationalization, and, at the same time, keep our historical identity.

Coordination of scientific internationalization and teaching is only part of the complete picture. In order to achieve our European adaptation, we require complete coordination among scientists, public power, commercial investors, teaching centres and citizen integration of scientific advances (López-Ocón Cabrera, 2003). An open discussion on teaching of science, and citizen integration, has also been initiated (e.g. www.csciencia2007.csic.es). Currently, some universities provide notions of social responsibility, which must also be taken into account (see www.educacion/ universidades...); for international references see Lim, 2003; and Gilbert and Fausto-Sterling, 2003). A book on scientifically wellfounded religious opinions on the human embryo dignity has also been published (Núñez de Castro, 2008). Some of these notions also represent new bridges between science and humanistic disciplines (Potter, 1971).

\section{Concluding remarks}

Reviewing this description of teaching of developmental biology in Spanish universities, I have been able to recognize some specific advances as well as urgent needs. We can guarantee that enough education on this subject is offered to an increasing population of about 26000 students each year. This education seems to be conceptually updated when compared to international teaching centres. However, in this article, efforts have been made to help university teachers to improve their classes on developmental biology. In general, I request strict guidelines of the Spanish Administration to support a compulsory position of a developmental-biology related subject in biology-related grades during future development. It is mandatory to convince them that developmental biology helps unifying biology by connecting genetics, molecular biology, cell biology, evolutionary biology, systematics or even applied mathematics in a single explanation of embryological evolution. But developmental biology also provides a valuable conceptual and practical tool to be applied in many jobs related to both basic (biology-related) and applied (health science, veterinary, agriculture or marine science) disciplines. Spanish university must be prepared to perform this double function of teaching both basic and applied-developmental biology in our promising future.

\section{Acknowledgements}

Institutional information has been obtained from the former Ministries of Education and Science, of Education, Social Politics and Sports and the current Ministry of Education (www.educacion.es), Junta de Andalucía (www.juntadeandalucia.es/educacion/), and at each university official page (www.educacion/universidades...). I am indebted to Prof. Juan Aréchaga for his invitation to collaborate with this article to this Special Issue. I am also indebted to Profs. Drs. Fernando Marín Girón, and José Becerra, founder of CABD, for providing me with the opportunity to enjoy teaching at the University of Málaga. I am also indebted to George Malacinski, José Becerra, Miguel Ángel Medina, Paul Palmqvist, Josefa Ruiz-Sánchez, Gloria Mari-Beffa, María Dolores López-Ávalos and Norma McVeigh for correction to this manuscript. I also acknowledge Dr. Carmen Murciano for explanations on embryological teaching at secondary schools in former LOGSE programs. The English texts between quotation marks are author's free translations.

\section{References}

ADAMS, D. S. (2003). Teaching critical thinking in a developmental biology course at an American liberal arts college. Int. J. Dev. Biol. 47: 145-151.

ALBERTS, B., BRAY, D., LEWIS, J., RAFF, M., ROBERTS, K. and WATSON, J. (2002). Molecular Biology of the Cell. 4th Edition. Garland Science, New York and London.

BARD, J. (Ed.) (1994). Embryos. Color Atlas of Development. Wolfe Publishing, London.

BROWDER, L. W. (2003). The role of textbooks in communicating developmental biology. Int. J. Dev. Biol. 47: 223-224.

CARLSON, B. M. (2000). Embriología Humana y Biología del desarrollo. $2^{\text {nd }}$ edition. Ediciones Harcourt, S. A., Madrid.

DEL PINO, E. M. (2003). Developmental biology in Ecuador: a 30-year teaching experience. Int. J. Dev. Biol. 47: 189-192.

DURÁN MUÑOZ, G. and ALONSO BURÓN, F. (1983). Cajal. Escritos Inéditos, Editorial científico-médica, Barcelona, p.44

GARCÍA DEL MORAL, L. F., LIGERO LIGERO, F., ROMERO MONREAL, L. and SÁNCHEZ CALLE, I. (1979). Prácticas de Fisiología Vegetal. Ediciones Universidad de Granada, Granada.

GARCíA SIMÓN, A. (Ed.) (1995). Historia de una Cultura. La singularidad de Castillall. Junta de Castilla y León. Consejería de Cultura y Turismo, Valladolid.

GHYSEN, A. (2009). Ontogeny of an adventurous mind: the origin of Antonio García-Bellido's contributions to developmental biology. Int. J. Dev. Biol. 53: 1277-1290. (doi: 10.1387/ijdb.072384ag)

GILBERT, S. F. (2005). Biología del Desarrollo. $7^{\text {th }}$ edition. Editorial Médica Panamérica, Buenos Aires.

GILBERT, S. F. and FAUSTO-STERLING, A. (2003). Educating for social responsibility: changing the syllabus of developmental biology. Int. J. Dev. Biol. 47: 237-244.

GRUNZ, H. (2003). Four decades of teaching developmental biology in Germany. Int. J. Dev. Biol. 47: 193-201.

HARWOOD, W. S. (2003). Course enhancement: a roadmap for devising activelearning and inquiry-based science courses. Int. J. Dev. Biol. 47: 213-221.

HOUILLÓN, Ch. (1977). Embriología. Ediciones Omega, S.A., Barcelona.

KALTHOFF, K. (2001). Analysis of biological development. $2^{\text {nd }}$ edition. McGrawHill, New York.

KEY, B. and NURCOMBE, V. (2003). Making developmental biology relevant to undergraduates in an era of economic rationalism in Australia. Int. J. Dev. Biol. 


\section{Manuel Marí-Beffa}

47: 105-115.

LIM, T.-M. (2003). Learning developmental biology has priority in the life sciences curriculum in Singapore. Int. J. Dev. Biol. 47: 117-121.

LÓPEZ PIÑERO, J. M. F., GLICK, T., NAVARRO, V. and PORTELA, E. (1983a). Diccionario histórico de la ciencia moderna en España. vol. 1. (A-K). Península, Barcelona.

LÓPEZ PIÑERO, J. M. F., GLICK, T., NAVARRO, V. and PORTELA, E. (1983b). Diccionario histórico de la ciencia moderna en España. vol. 2. (L-Z). Península, Barcelona.

LÓPEZ-OCÓN CABRERA, L. (2003). Breve historia de la Ciencia Española. Historia de la Ciencia. Alianza Editorial, S. A., Madrid.

MALACINSKI, G. M. (2003). Student-oriented learning: an inquiry-based developmental biology lecture course. Int. J. Dev. Biol. 47: 135-140.

MARCO-CUELLAR, R. and ARÉCHAGA, J. (2009). Early bases of modern Embryology in Spain: Microscopical Anatomy and the introduction of Cell Theory and Histology in their scientific and social European context Int. J. Dev. Biol. 53: 1123-1143. (doi: 10.1387/ijdb.093020rm).

MARÍ-BEFFA, M. and KNIGHT, J. (Eds.) (2005). Key Experiments in Practical Developmental Biology. Cambridge University Press, Cambridge.

MARÍ-BEFFA, M., SANTAMARÍA, J. A., MURCIANO, C., SANTOS-RUIZ, L., ANDRADES, J. A., GUERADO, E. and BECERRA, J. (2007). Zebrafish fins as a model system for skeletal human studies. TSW Dev. Embryol. 2: 112-125.

MARTÍNEZ-ARIAS, A. and STEWART, A. (2002). Molecular Principles of Animal Development. Oxford University Press, Inc., New York.

MOORE, K. L. and PERSAUD, T. V. N. (2004). Embriología Clínica. $7^{\text {th }}$ edition. Ed. Harcourt, S. A, Madrid.

MUÑOZ-CHÁPULI, R., QUESADA, A. R. and MEDINA, M. A. (2004). Angiogenesis and signal transduction in endothelial cells. CMLS, Cell. Mol. Life Sci. 61: 22242243.

NÚÑEZ DE CASTRO, I. (2008) De la dignidad del embrión. Reflexiones en torno a la vida humana naciente. Cátedra de Bioética 16. Universidad Pontificia de Comillas. Publicaciones de la Universidad Pontificia Comillas, Madrid.

ORTEGA Y GASSET, J. (1930) Misión de la Universidad. Revista de Occidente, S. A., Madrid.

POTTER, V. R. (1971). Bioethics: Bridge to the future. Prentice Hall, Englewood Cliffs, New Jersey.

PUELLES, L. (2009). Contributions to Neuroembryology of Santiago Ramon y Cajal (1852-1934) and Jorge F. Tello (1880-1958). Int. J. Dev. Biol. 53: 1145-1160. (doi: 10.1387/ijdb.082589lp).

RAMÓN Y CAJAL, S. (1981). Recuerdos de mi vida: Historia de mi labor científica., pp. 30, 89. Alianza Editorial, S. A., Madrid.

SADLER, T. W. (2004). Langman. Embriología médica con Orientación Clínica. $9^{\text {th }}$ edition. Ed. Médica Panamericana, Madrid.

SÁNCHEZ CARRALERO, J. (2004) Libro blanco. Título de Grado en Biología. Agencia Nacional de Evaluación de la Calidad y Acreditación.

SÁNCHEZ DÍAZ, M., APARICIO TEJO, P. and PEÑA CALVO, J. I. (1980). Prácticas de Fisiología Vegetal. Ediciones Universidad de Navarra, Pamplona.

SIMON, E. and MOYSSET, L. (2001). Prácticas de Crecimiento y Desarrollo de los Vegetales. Textos docentes 248. Ediciones Universitat de Barcelona, Barcelona.

SLACK, J. M. W. (2006). Essential Developmental Biology. $2^{\text {nd }}$ edition. Blackwell Publishing, Malden.

TYLER, M.S., KOZLOWSKI, R.N. and GILBERT, S.F. (2003). Differential expression (cd-rom): Key experiments in developmental biology. Sinauer Associates, Sunderland.

WORRELL, M. B. (2007). Review of the book "Marí-Beffa, M. and Knight, J. (eds.) (2005)". J. Mammal. 8: 262.

WOLPERT, L., JESSELL, T., LAWRENCE, P., MEYEROWITZ, E., ROBERTSON, E. and SMITH, J. (2010). Principios de Desarrollo. 3rd Edition. Ed. Médica Panamericana, Madrid, Spain..

\section{Internet sources}

http://ec.europa.eu/education/lifelong-learning-programme/doc78_en.htm http://ec.europa.eu/education/policies/educ/bologna/bologna.pdf http://www.educacion.es/educacion/universidades/educacion-superioruniversitaria/que-estudiar-donde/universidades-espanolas.html and references within.

http://ensciencias.uab.es

http://noticias.juridicas.com/base_datos/Admin/constitucion.t1.html\#c2 (Teaching freedom)

http://web.micinn.es/

http://www.boe.es/dias/2005/01/25/pdfs/A02842-02846.pdf (The new grade).

http://www.boe.es/boe/dias/2007/11/06/pdfs/A45381-45477.pdf (New secondary school programs)

http://www.cambridge.org/catalogue/catalogue.asp?isbn=9780521833158\&ss=fro http://www.cbm.uam.es/cantoblancows

http://www.co-operation.org/

http://www.csciencia2007.csic.es

http://www.educacion.es/portada.html

http://www.exclusivebooks.com

http://www.fundacionprincipedeasturias.org/esp/index.html

http://www.juntadeandalucia.es/educacion

http://www.march.es/crib/anteriores/2005.asp

http://www.natureasia.com/

http://www.newhorizons.org

http://www.oui-iohe.org/eles/espacios-comunes/latinoamericano/

http://www.uclm.es/PROFESORADO/RICARDO/LOGSE.html (Old secondary school programs)

http://www.uimp.es/en

http://www.unia.es/

http://www.upo.es/CABD

http://www.uwex.edu/ce/

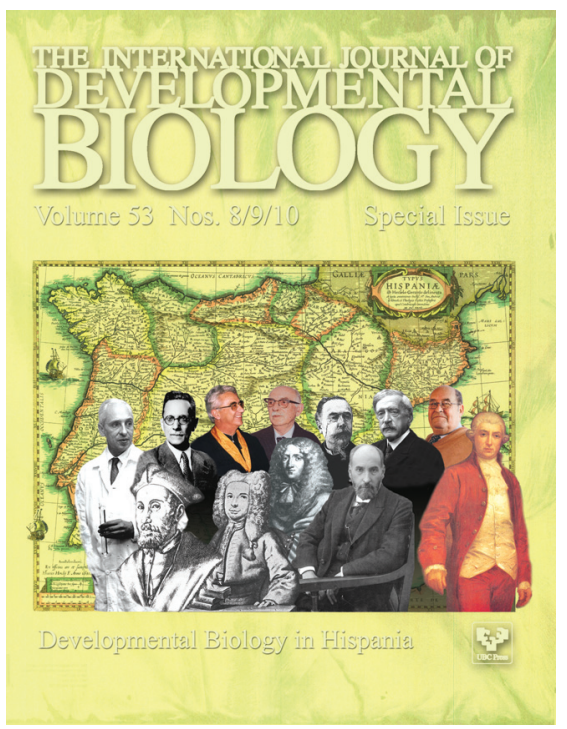




\section{Further Related Reading, published previously in the Int. J. Dev. Biol.}

See our recent Special Issue Teaching Developmental Biology edited by George M. Malacinski and Susan T. Duhon at: http://www.ijdb.ehu.es/web/contents.php?vol=47\&issue=2-3

See Special Issue Pattern Formation edited by Michael K. Richardson and Cheng-Ming Chuong at: http://www.ijdb.ehu.es/web/contents. php?vol=53\&issue=5-6

Four decades of teaching developmental biology in Germany.

Horst Grunz

Int. J. Dev. Biol. (2003) 47: 193-201

Virtual labs: a substitute for traditional labs?

Rebecca K Scheckler

Int. J. Dev. Biol. (2003) 47: 231-236

Developmental biology in Ecuador: a 30-year teaching experience.

Eugenia $\mathrm{M}$ del Pino

Int. J. Dev. Biol. (2003) 47: 189-192

Teaching critical thinking in a developmental biology course at an American liberal arts college.

Dany S Adams

Int. J. Dev. Biol. (2003) 47: 145-151

Using models to enhance the intellectual content of learning in developmental biology. John C McLachlan

Int. J. Dev. Biol. (2003) 47: 225-229

Teaching embryology to undergraduates in the Faculty of Education at Dokuz Eylul University in Izmir, Turkey.

Irfan Yilmaz

Int. J. Dev. Biol. (2003) 47: 141-144

From field to gel blot: teaching a holistic view of developmental phenomena to undergraduate biology students at the University of Tokyo.

Takashi Ariizumi and Makoto Asashima

Int. J. Dev. Biol. (2003) 47: 93-97

Learning-developmental biology has priority in the life sciences curriculum in Singapore.

Lim, T.-M.

Int. J. Dev. Biol. (2003) 47:117-121.

Course enhancement: a roadmap for devising active-learning and inquiry based science courses.

Harwood, W.S.

Int. J. Dev. Biol. (2003) 47:213-221.

Student-oriented learning: an inquiry-based developmental biology lecture course. Malacinski, G.M.

Int. J. Dev. Biol. (2003) 47:135-140.

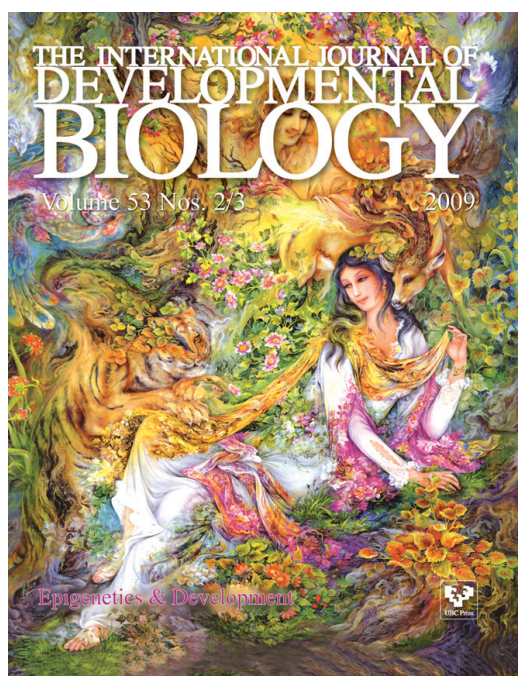

5 yr ISI Impact Factor $(2008)=3.271$

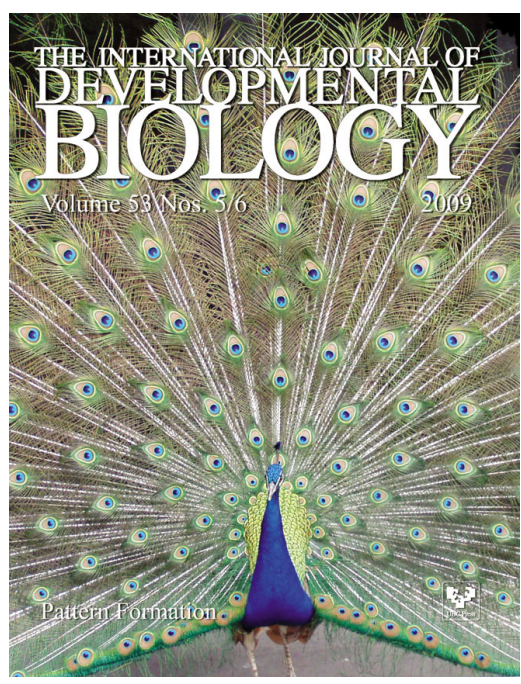

